\title{
EXPERIMENTAL AND THEORETICAL INVESTIGATION OF ACETONE EVAPORATION
}

\author{
Levente Tugyi \\ PhD student, University of Miskolc, Institute of Energy engineering and Chemical Machinery, \\ Department of Chemical Machinery \\ 3515 Miskolc, Miskolc-Egyetemváros, e-mail: vegytl@uni-miskolc.hu
}

Zoltán Siménfalvi

associate professor, University of Miskolc, Institute of Energy engineering and Chemical Machinery, Department of Chemical Machinery

3515 Miskolc, Miskolc-Egyetemváros, e-mail: simenfalvi@uni-miskolc.hu

Gábor L. Szepesi

associate professor, University of Miskolc, Institute of Energy engineering and Chemical Machinery, Department of Chemical Machinery

3515 Miskolc, Miskolc-Egyetemváros, e-mail: szepesi@uni-miskolc.hu

\begin{abstract}
In the case of flammable liquids, it is known that is not the liquid itself that is prone to ignition, but the vapour of the hazardous substance. For these substances, it is particularly important to be able to determine exactly how much vapour is produced and how it spreads. The substance to be tested is acetone. That is a common substance in households in various forms (cosmetics), but is also frequently used in the chemical industry. Different models are available for calculating the evaporation rate, which are compared in this study with the evaporation experiments carried out. The aim is to select a suitable model in relation to the measured results.
\end{abstract}

Keywords: acetone, flammable liquid, evaporation, diffusion

\section{Introduction}

Many flammable liquids are used in a different of chemical equipment, such as tanks, columns, heat exchangers and so on. This equipment may occur some form of leakage under normal operating conditions. These phenomena can result from unintentional human error or technical failure.

Leakage can cause the formation of a pool. From the surface of the pool the (ambient heat) causes in evaporation that results in turning the liquid into vapour. The Figure 1 shows which the phase of acetone occurs as the different pressures and temperatures (P-T).

Acetone's vapour is potentially flammable, can form a hazardous atmosphere. The vapour cloud from the pool can spread in the environment. It becomes steadily more diluted and less concentrated.

Many flammable liquids are used in a different of chemical equipment, such as tanks, columns, heat exchangers and so on.

The evaporation rate depends largely on the extent on the surface area of the pool and the literature defines two types of pool by extent, bounded and unbounded.

In this study, the chosen liquid was acetone for which the phenomenon of evaporation was tested using several speed of air flow velocities. A small amount of acetone in liquid form was placed in a 
glass crucible and tested with no air flow first. Then, the test was repeated with air velocities of 2-4-6 $\mathrm{m} / \mathrm{s}$, because the different air flow velocities can increase the rate of evaporation. By comparing the results of the measurements with several types of evaporation models. The study concludes which calculation model are closest for the experiments carried out.

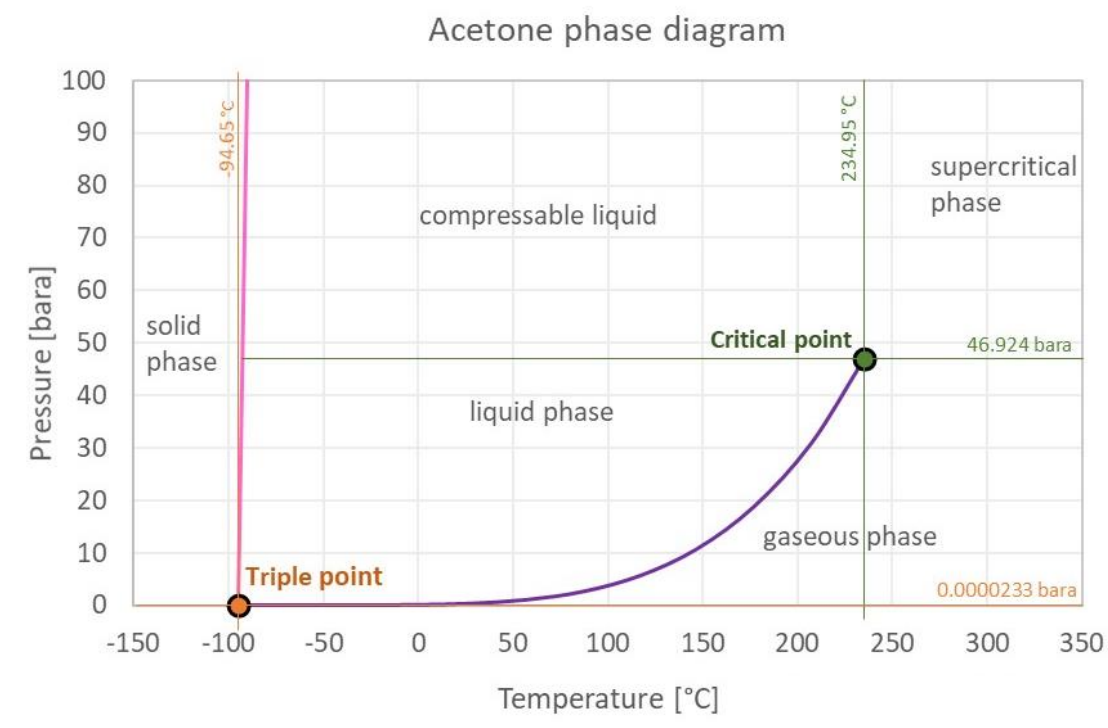

Figure 1. Acetone phase diagram. (Engineering ToolBox, 2021)

\section{Evaporation}

Evaporation of the liquid can occur above the melting point. Above this point with rising the temperature accelerates evaporation. In addition, the area of surface of liquid also affects the rate of evaporation. These properties depend on the rate of formation, which is related to the amount of vapour above the liquid.

The evaporation rate depends on many parameters. First of all, it depends on the temperature of the liquid (Crowl and Louvar, 2011). At higher temperatures, the molecules move faster, thus they can escape from the surface more easily. The substances are different as chemical and physic properties, therefore have different evaporation rates (van den Bosch et al., 1997; Tiemessen and Heitink, 1999). In summary, evaporation depends mainly on temperature, ambient pressure, air flow and the structural properties of the material.

The $q_{v}^{m}$ is the local vaporisation flux, which can be defined by the following relation (van den Bosch et al., 1997):

where

$$
q_{v}^{m}=k_{m} \cdot c_{i}
$$

- $q_{v}^{m}$ is the average local evaporation coefficient $\left(\frac{\mathrm{kg}}{\mathrm{m}^{2} \cdot \mathrm{s}}\right)$,

- $k_{m}$ is the concentration-related mass transfer coefficient $\left(\frac{m}{s}\right)$, 
- $\quad c_{i}$ is the concentration component $\left(\frac{\mathrm{kg}}{\mathrm{m}^{3}}\right)$.

The atmospheric concentration at the surface of the liquid depends on the saturated vapour pressure and the temperature of the material (van den Bosch et al., 1997):

$$
c_{i} \approx f\left(P_{v}, T\right)
$$

where

$-P_{v}, T$ is the saturated vapour pressure at a given temperature in Kelvin.

\section{One-way diffusion}

One-way diffusion means that one component does not dissolve in the phase of the other component. (Fábry, 1989). Evaporation is mostly a one-way diffusion process.

In a two-phase system, where components $\mathrm{X}$ and $\mathrm{Y}$ are present and only $\mathrm{X}$ can dissolve in $\mathrm{Y}$. The diffusion flux develops in the boundary layer of phase $Y$, where the $X$ component moves from the phase boundary towards the interior of phase Y (Gulyás, 2011). Figure 2 helps to better understand this process.

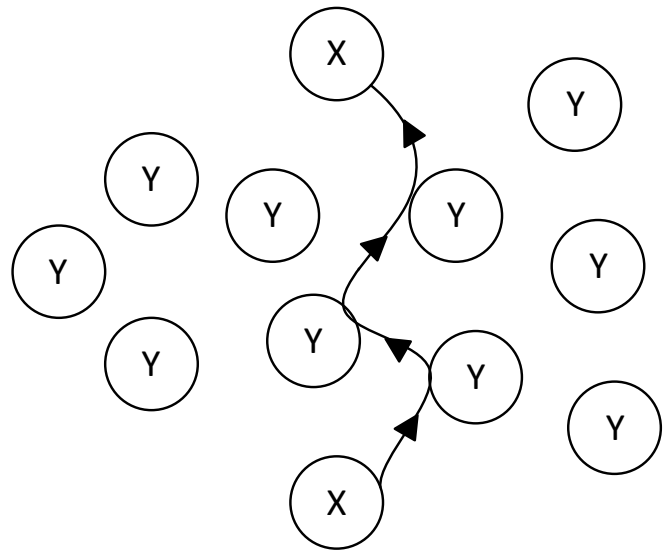

Figure 2. Diffusion flux in the boundary layer. (Sattler, 1983)

As shown in the previous figure, the $\mathrm{Y}$ component cannot diffuse into the $\mathrm{X}$ phase by surface diffusion. There is no possibility of bidirectional diffusion, so the following equation can be written (Treybal, 1961):

$$
J_{X}=c_{X} u_{o}-D_{X Y} \frac{d c_{X}}{d z}
$$

where

- $J_{X}$ is the current density of the X component $\left(\frac{\mathrm{kg}}{\mathrm{m}^{2} \cdot s}\right)$,

- $c_{X}$ is the concentration of $\mathrm{X}$ component $\left(\frac{\mathrm{mol}}{\mathrm{m}^{3}}\right)$, 
- $u_{0}$ is the average flow velocity in the direction of diffusion $\left(\frac{m}{s}\right)$,

- $D_{X Y}$ is diffusion coefficient of component X in medium Y $\left(\frac{m^{2}}{s}\right)$.

Since diffusion is not bidirectional, there is only one-way mole and volume flow. In the gas phase, the equation for the relationship between the density and velocity of the molecule current can be written (Treybal, 1961):

$$
u_{o}=\frac{J_{X}}{\rho_{M}}
$$

Unit of density is $\rho_{m}\left(\frac{\mathrm{kg}}{\mathrm{m}^{3}}\right)$. Substituting equation (4) back into equation (3), obtain the differential equation for one-way diffusion after the rearrangement (Treybal, 1961):

$$
J_{X}=-D_{X Y} \frac{\rho_{M}}{\rho_{M}-c_{A}} \frac{d c_{X}}{d z}
$$

For one-way diffusion, the concentration change is consistent. The function of both components is symmetric in terms of concentration difference and diffusion direction. This illustrated in Figure 3 (Fábry, 1989; Gulyás, 2011).

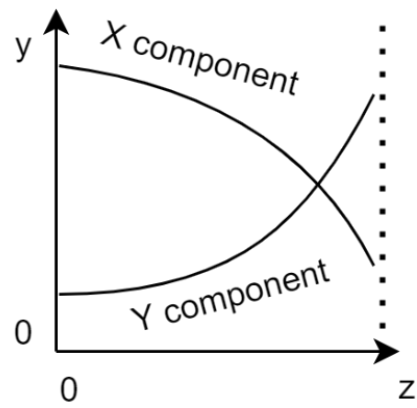

Figure 3. Concentration change as a function of location. (Fábry, 1989; Gulyás, 2011)

Evaporation of acetone is a one-way diffusion process between liquid and gas phase which affects the propagation model of the substance.

\section{Experimental evaporation test}

During the evaporation experimental of acetone, the same measurement was carried out under different conditions:

- evaporation without air flow,

- evaporation with $2 \mathrm{~m} / \mathrm{s}$ air flow,

- evaporation with $4 \mathrm{~m} / \mathrm{s}$ air flow,

- evaporation with $6 \mathrm{~m} / \mathrm{s}$ air flow,

An analytical balance is used to monitor rate of the evaporation. This provides analysable data on the variation of the amount of acetone in the glass crucible. In the case of measurements with air flow. 
The balance was very sensitive so the values of the scale were constantly fluctuating due to the wind speed. It was not possible to read clearly from the equipment when the acetone had evaporated. It was necessary to constantly check the moment when the liquid had completely evaporated by visual inspection. The measurement process is shown in Figure 4 and detailing the different units.

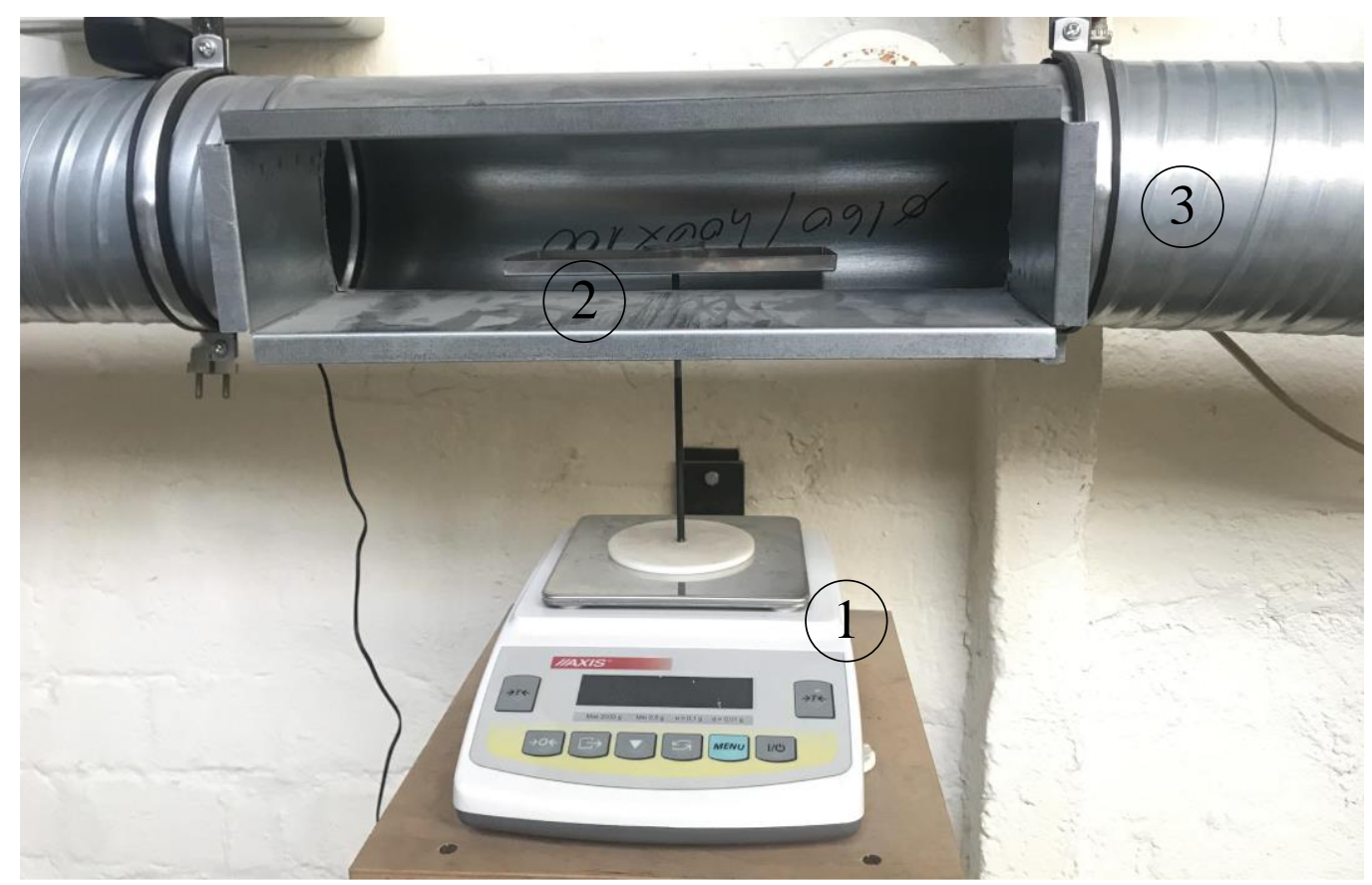

Figure 4. Measurement process: 1-analytic balance, 2-glass crucibe, 3-air duct

\subsection{Evaporation without air flow}

The liquid surface and the ambient temperature were the same for all measurements, but the initial mass values were not always the same, but this did not affect the evaporation rate in the evaluation.

The parameters of the respective measurements are summarized in Table 1 followed by the measured where

- $A$ is area of liquid surface $\left(m^{2}\right)$,

- $T$ is the ambient temperature $\left({ }^{\circ} \mathrm{C}\right)$,

- $m_{0}$ is mass of acetone at the beginning of the measurement $(\mathrm{mg})$,

- $m_{1}$ is mass of acetone at the end of the measurement $(m g)$,

- $t$ is the total evaporation time $(s)$.

Evaporation function is in Figure 5. (from which the evaporation rate can be determined)

Table 1. Mass change in case of without air flow

\begin{tabular}{|c|c|c|c|c|}
\hline$A$ & $T$ & $m_{0}$ & $m_{1}$ & $t$ \\
\hline 0.00096 & 33 & 1860 & 1600 & 287.6 \\
\hline
\end{tabular}




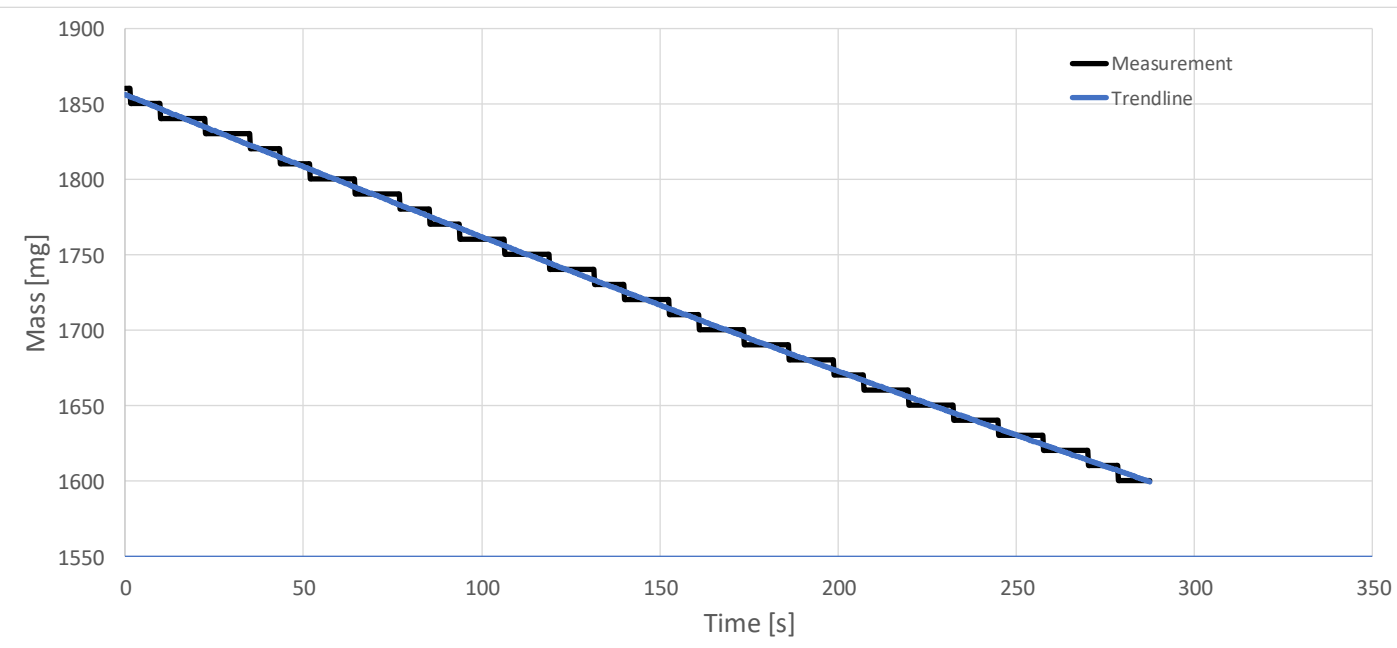

Figure 5. Mass change in case of no air flow

The measurement is marked by the black function, which shows a staggered progression. By overlaying the blue trendline, the best fitting linear line is shown.

The amount evaporated from the surface of the liquid during the measurement period as a function of time gives the following evaporation rate:

$$
v=0.904 \frac{m g}{s}
$$

\subsection{Evaporation with $2 \mathrm{~m} / \mathrm{s}$ air flow}

In case where the evaporation variation is already examined in conjunction with air flow, the liquid evaporates completely. The experiments also show that the evaporation rate varies. Evaporation accelerated with increasing speed. Less time also was enough for the liquid to evaporate completely. The measurement parameters are given in Table 2 and the associated diagram is shown in Figure 6 (a smaller quantity was measured than in the previous case).

Table 2. Mass change in case of $2 \mathrm{~m} / \mathrm{s}$ air flow

\begin{tabular}{|c|c|c|c|c|}
\hline$A$ & $T$ & $m_{0}$ & $m_{1}$ & $t$ \\
\hline 0.00096 & 33 & 1370 & 0 & 222 \\
\hline
\end{tabular}

Figure 6 is shown that during the air flow measurement the balance detected high, scattered values. It was even possible to fit a trend line on it. Which shows the evaporation process. The function of time gives the following evaporation rate, the rate being (of course, the speed increased):

$$
v=6.171 \frac{m g}{s}
$$




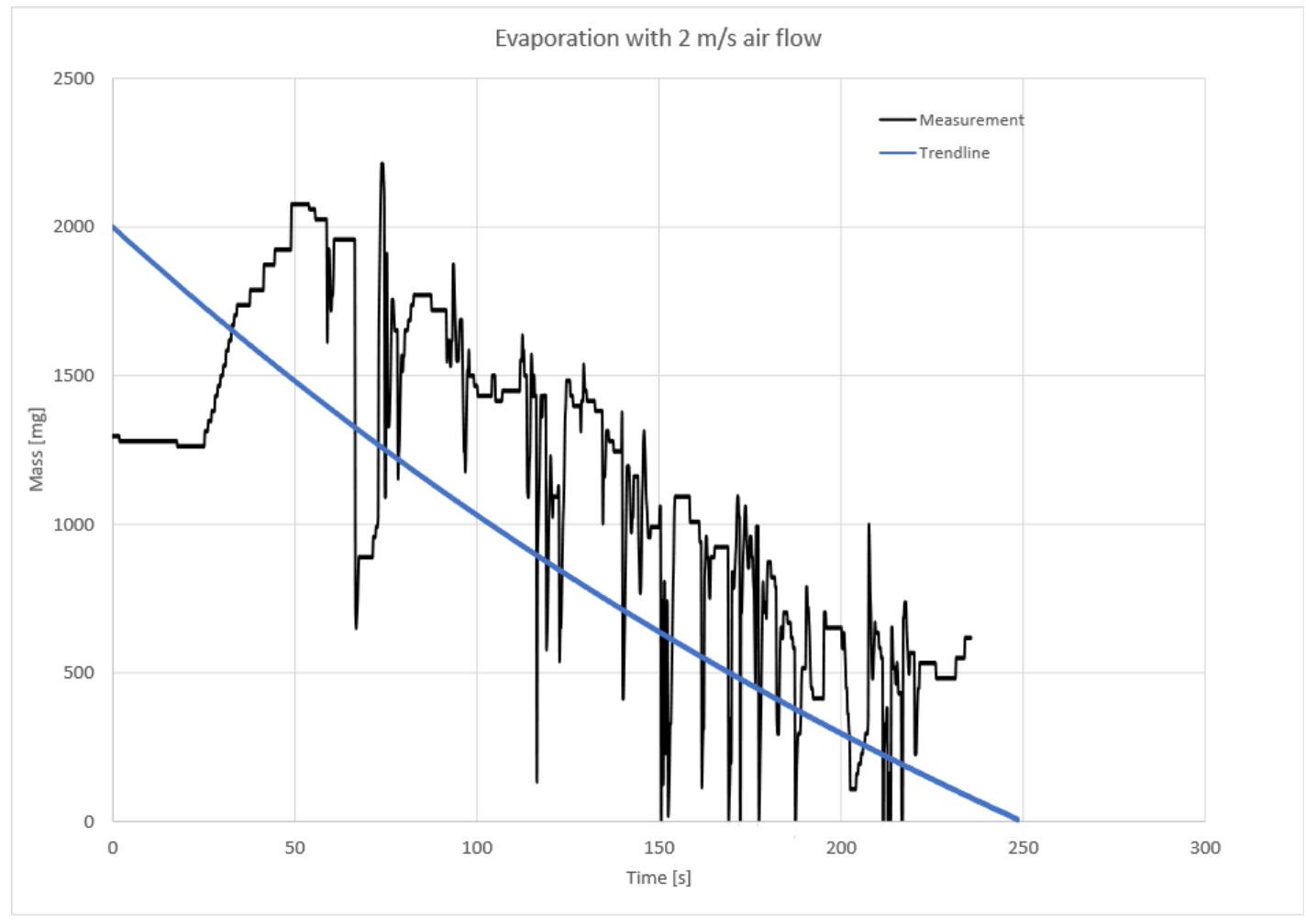

Figure 6. Mass change in case of $2 \mathrm{~m} / \mathrm{s}$ air flow

\subsection{Evaporation with $4 \mathrm{~m} / \mathrm{s}$ air flow}

With increased air flow, the rate of evaporation increases and it is found that the increase in air flow is proportional to the increase in evaporation rate but not in a linear trend. The measurement parameters are given in Table 3.

Table 3. Mass change in case of $4 \mathrm{~m} / \mathrm{s}$ air flow

\begin{tabular}{|c|c|c|c|c|}
\hline$A$ & $T$ & $m_{0}$ & $m_{1}$ & $t$ \\
\hline 0.00096 & 33 & 2080 & 0 & 223.4 \\
\hline
\end{tabular}

The amount evaporated from the surface of the liquid during the measurement period as a function of time gives the following evaporation rate with $4 \mathrm{~m} / \mathrm{s}$ air flow:

$$
v=9.311 \frac{\mathrm{mg}}{\mathrm{s}}
$$

\subsection{Evaporation with $6 \mathrm{~m} / \mathrm{s}$ air flow}

The even higher air flow makes the acetone evaporate even faster, this forming a flammable vapour cloud more quickly. The measurement parameters are given in Table 4. 
Table 4. Mass change in case of $6 \mathrm{~m} / \mathrm{s}$ air flow

\begin{tabular}{|c|c|c|c|c|}
\hline$A$ & $T$ & $m_{0}$ & $m_{1}$ & $t$ \\
\hline 0.00096 & 33 & 2160 & 0 & 167,8 \\
\hline
\end{tabular}

The amount evaporated from the surface of the liquid during the measurement period as a function of time gives the following evaporation rate with $6 \mathrm{~m} / \mathrm{s}$ air flow:

$$
v=12.8 \frac{\mathrm{mg}}{\mathrm{s}}
$$

It can be seen that for the three experiments where a given air flow touched the liquid surface, the rate of evaporation increased.

\section{Comparison of evaporation models}

There are plenty of literature on evaporation models, including the following 5 models of calculation for acetone evaporation:

- Olander evaporation rate model (Olander, 1994).

- Olander evaporation rate model with factors (Olander, 1994).

- Evaporation rate model without air flow (U. S. Env. Prot. Agency, 1994).

- Evaporation rate model (U. S. Env. Prot. Agency, 1994).

- Evaporation rate model from paint and ink production (Eastern Research Group, 2000).

The models are presented in further subsections, listed in order with a description of the structure and operational steps in each case.

Examining these models with the parameters of previous experiments carried out. They show different results. The aim is to find the model whose results are closest to the measured results.

\subsection{Model 1 - Olander evaporation rate model}

The first two models use the relationships developed by Lars Olander (Olander, 1994), a Swedish researcher. His studies form the basis of much subsequent research. The chemical and physical properties of acetone are given and the values of the constant and variable parameters of the experimental conditions are integrated into the models.

$$
v_{1}=3.6 \cdot 10^{-8}\left(\frac{M \cdot p}{T}\right) \cdot u^{0.78} \cdot r^{1.89}
$$

The constant parameters depend partly on the temperature value:

- $M$ is the molar mass of acetone $\left(58.08 \frac{\mathrm{g}}{\mathrm{mol}}\right)$,

- $T$ is the ambient temperature $(306.15 K)$,

- $r$ is the radius of the liquid surface $(1.75 \mathrm{~cm})$,

- $\quad p$ is the vapor pressure of acetone at $25.0{ }^{\circ} \mathrm{C}\left(305933.549 \frac{\mathrm{dyn}}{\mathrm{cm}^{2}}\right)$. 
The only variable parameter is the value of air flow:

- $u$ is the air flow $\left(\frac{m}{s}\right)$.

The models use different dimensions for each parameter, so they are not uniform but the results are comparable.

\subsection{Model 2 - Olander evaporation rate model with factors}

The factor to the previous model changes the context of the model and results in the following formulae:

$$
\begin{gathered}
v_{2}=0.3 \cdot u^{0.8} \cdot A^{0.9} \cdot T^{-0.8} \cdot M \cdot p\left[\frac{\left(3.1+\rho^{-0.33}\right)^{2}}{K}\right]^{-0.67} \\
K=T^{0.5} \cdot\left(\frac{1}{29}+\frac{1}{M}\right)^{0.5}
\end{gathered}
$$

The constant parameters depend partly on the temperature value:

- $M$ is the molar mass of acetone $\left(58.08 \frac{\mathrm{g}}{\mathrm{mol}}\right)$,

- $T$ is the ambient temperature $(306.15 K)$,

- $A$ is the surface of the liquid $\left(0.00096 m^{2}\right)$,

- $\rho$ is the density of acetone $\left(13505.51 \frac{\mathrm{mol}}{\mathrm{m}^{3}}\right)$,

- $\quad p$ is the vapor pressure of acetone at $25.0^{\circ} \mathrm{C}(229.469 \mathrm{mmHg})$.

The only variable parameter is the value of air flow:

- $u$ is the air flow $\left(\frac{m}{s}\right)$.

\subsection{Model 3 - Evaporation rate without air flow}

The Model 3 was developed within the United States Environmental Protection Agency's Risk Management Program in the late 1990s. The researchers analysed at the unmitigated releases of toxic liquids which are flammable and can create hazardous area (U. S. Env. Prot. Agency, 1994):

$$
\begin{gathered}
v_{3}=1.4 \cdot L F A \cdot A \\
L F A=\frac{0.284 \cdot M^{2 / 3} \cdot p}{R \cdot T}
\end{gathered}
$$

The constant parameters depend partly on the temperature value:

- $M$ is the molar mass of acetone $\left(58.08 \frac{\mathrm{g}}{\mathrm{mol}}\right)$, 
- $T$ is the ambient temperature $(306.15 K)$,

- $A$ is the surface of the liquid $\left(0.01033 f t^{2}\right)$,

- $R$ is the universal gas constant $\left(82.05 \frac{\mathrm{atm} \cdot \mathrm{cm}^{3}}{\mathrm{gmol} \cdot \mathrm{K}}\right)$,

- $\quad p$ is the vapor pressure of acetone at $25.0^{\circ} \mathrm{C}(229.469 \mathrm{mmHg})$.

\subsection{Model 4 - Evaporation rate}

This model is based on the previous model but also uses other factors:

$$
v_{4}=\frac{0.284 \cdot u^{0,78} \cdot M^{2 / 3} \cdot A \cdot p}{R \cdot T}
$$

The constant parameters depend partly on the temperature value:

- $M$ is the molar mass of acetone $\left(58.08 \frac{\mathrm{g}}{\mathrm{mol}}\right)$,

- $T$ is the ambient temperature $(306.15 K)$,

- $A$ is the surface of the liquid $\left(0.01033 f t^{2}\right)$,

- $R$ is the universal gas constant $\left(82.05 \frac{\mathrm{atm} \cdot \mathrm{cm}^{3}}{\mathrm{gmol} \cdot \mathrm{K}}\right)$,

- $\quad p$ is the vapour pressure of acetone at $25.0^{\circ} \mathrm{C}(229.469 \mathrm{mmHg})$.

The only variable parameter is the value of air flow:

- $u$ is the air flow $\left(\frac{m}{s}\right)$.

\subsection{Model 5 - Evaporation rate model from paint and ink production}

This model also associated with researchers in the United States. The reason for developing this model is the drying time of the paint and the formation of a hazardous area. This evaporative emissions from painting were considered and the following relationships were developed (Eastern Research Group, 2000):

$$
\begin{gathered}
v_{5}=\frac{M \cdot K \cdot A \cdot p}{R \cdot T} \\
K=0.00438 \cdot u^{0.78} \cdot\left(\frac{18}{M}\right)^{1 / 3}
\end{gathered}
$$

The constant parameters depend partly on the temperature value:

- $M$ is the molar mass of acetone $\left(58.08 \frac{\mathrm{g}}{\mathrm{mol}}\right)$, 
- $T$ is the ambient temperature $\left(551,07^{\circ} R\right)$,

- $A$ is the surface of the liquid $\left(0.01033 f t^{2}\right)$,

- $R$ is the universal gas constant $\left(10,73 \frac{\mathrm{psia} \cdot \mathrm{ft}^{3}}{{ }^{\circ} \mathrm{R} \cdot \mathrm{lbmol}}\right)$,

- $\quad p$ is the vapor pressure of acetone at $25.0^{\circ} \mathrm{C}(229.469 \mathrm{mmHg})$.

The only variable parameter is the value of air flow:

- $u$ is air flow $\left(\frac{m}{s}\right)$.

\section{Evaluation of evaporation models and comparison with experimental results}

The results of the obtained evaporation rates are summarized in Table 5. Detailing the values of the different experimental conditions in relation to each other. In the test with no air flow, it was assumed to be a negligible $0.2 \mathrm{~m} / \mathrm{s}$ because of Brownian motion (Brilliantov and Pöschel, 2004). Otherwise some certain models could not be applied without air flow variable.

Table 5. Comparison of models.

\begin{tabular}{|c|c|c|c|c|}
\hline & $\mathrm{u}=0.2 \mathrm{~m} / \mathrm{s}$ & $\mathrm{u}=2 \mathrm{~m} / \mathrm{s}$ & $\mathrm{u}=4 \mathrm{~m} / \mathrm{s}$ & $\mathrm{u}=6 \mathrm{~m} / \mathrm{s}$ \\
\hline Model 1 & $\mathrm{v}_{1}=1.714 \mathrm{mg} / \mathrm{s}$ & $\mathrm{v}_{1}=10.332 \mathrm{mg} / \mathrm{s}$ & $\mathrm{v}_{1}=17.741 \mathrm{mg} / \mathrm{s}$ & $\mathrm{v}_{1}=24.341 \mathrm{mg} / \mathrm{s}$ \\
\hline Model 2 & $\mathrm{v}_{2}=11.838 \mathrm{mg} / \mathrm{s}$ & $\mathrm{v}_{2}=74.696 \mathrm{mg} / \mathrm{s}$ & $\mathrm{v}_{2}=130.053 \mathrm{mg} / \mathrm{s}$ & $\mathrm{v}_{2}=179.884 \mathrm{mg} / \mathrm{s}$ \\
\hline Model 3 & $\mathrm{v}_{3}=4.254 \mathrm{mg} / \mathrm{s}$ & $\mathrm{v}_{3}=4.25 \mathrm{mg} / \mathrm{s}$ & $\mathrm{v}_{3}=4.254 \mathrm{mg} / \mathrm{s}$ & $\mathrm{v}_{3}=4.254 \mathrm{mg} / \mathrm{s}$ \\
\hline Model 4 & $\mathrm{v}_{4}=0.904 \mathrm{mg} / \mathrm{s}$ & $\mathrm{v}_{4}=5.449 \mathrm{mg} / \mathrm{s}$ & $\mathrm{v}_{4}=9.356 \mathrm{mg} / \mathrm{s}$ & $\mathrm{v}_{4}=12.837 \mathrm{mg} / \mathrm{s}$ \\
\hline Model 5 & $\mathrm{v}_{5}=0.037 \mathrm{mg} / \mathrm{s}$ & $\mathrm{v}_{5}=0.221 \mathrm{mg} / \mathrm{s}$ & $\mathrm{v}_{5}=0.381 \mathrm{mg} / \mathrm{s}$ & $\mathrm{v}_{5}=0.523 \mathrm{mg} / \mathrm{s}$ \\
\hline
\end{tabular}

It can be seen that for Model 3, where there is no air speed factor, all results are the same. This model is recommended for use in a completely enclosed space, where air flow is almost zero. This condition is difficult to be met because opening and closing a window or door also causes air flow. This air flow can persist for a long period of time, but it slowly and steadily diminishes over time. There are always small eddies with an average of zero but at a given point they can change direction and appear as air flow. In the other cases, the evaporation rate values increase with the air flow value.

Examining the experimental and model results obtained, it can be concluded that for this type of evaporation Model . is the closest to the measured values. The comparison of these results is shown in Table 6 and Figure 7.

Table 6. Results of measurements and Model 4

\begin{tabular}{|c|c|c|c|c|}
\hline & $\mathrm{u}=0.2 \mathrm{~m} / \mathrm{s}$ & $\mathrm{u}=2 \mathrm{~m} / \mathrm{s}$ & $\mathrm{u}=4 \mathrm{~m} / \mathrm{s}$ & $\mathrm{u}=6 \mathrm{~m} / \mathrm{s}$ \\
\hline Measurements & $\mathrm{v}=0.904 \mathrm{mg} / \mathrm{s}$ & $\mathrm{v}=6.171 \mathrm{mg} / \mathrm{s}$ & $\mathrm{v}_{1}=9.311 \mathrm{mg} / \mathrm{s}$ & $\mathrm{v}_{1}=12.8 \mathrm{mg} / \mathrm{s}$ \\
\hline Model 4. & $\mathrm{v}_{4}=0.904 \mathrm{mg} / \mathrm{s}$ & $\mathrm{v}_{4}=5.449 \mathrm{mg} / \mathrm{s}$ & $\mathrm{v}_{4}=9.356 \mathrm{mg} / \mathrm{s}$ & $\mathrm{v}_{4}=12.837 \mathrm{mg} / \mathrm{s}$ \\
\hline
\end{tabular}




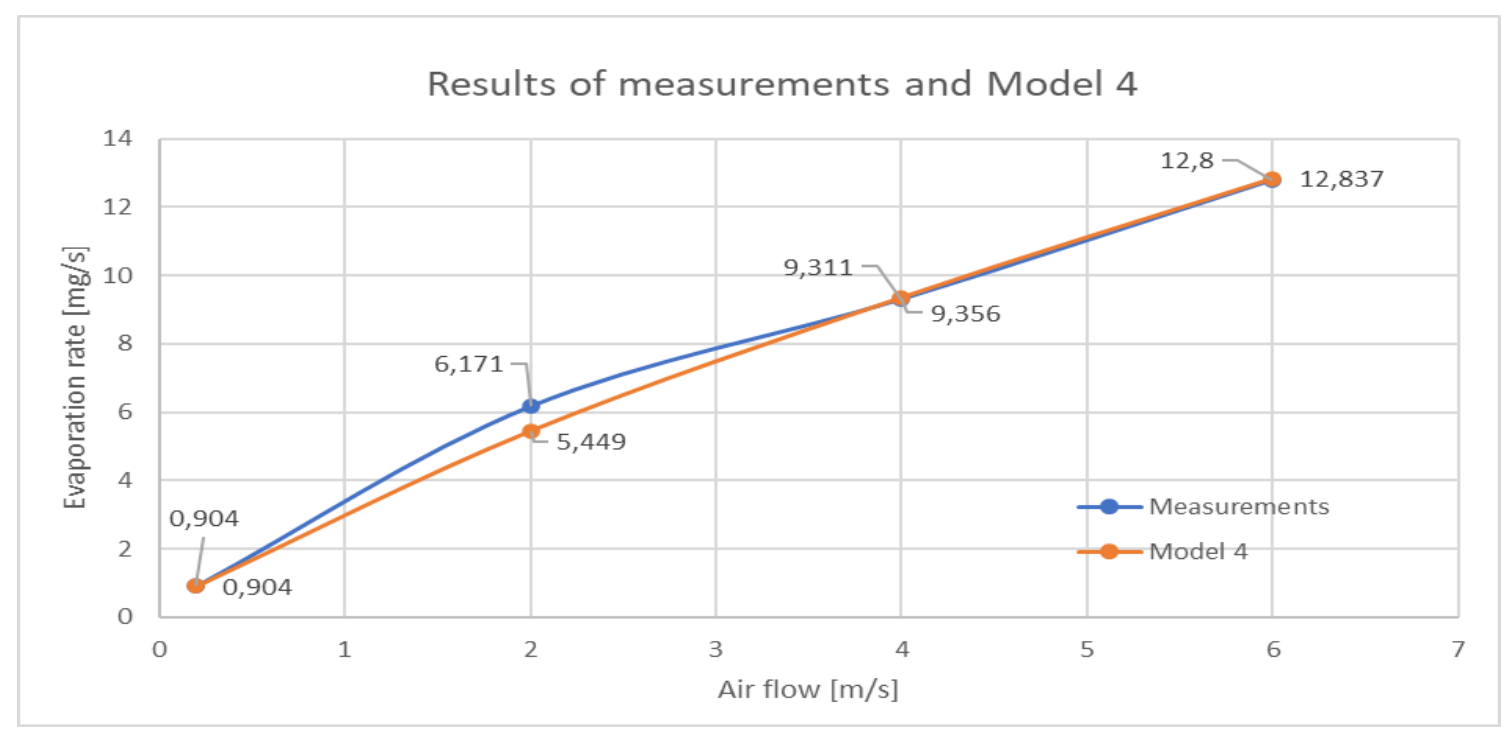

Figure 7. Results of measurements and Model 4.

This model gives the same result to within four decimal places of the measurements, except for the $2 \mathrm{~m} / \mathrm{s}$ case, where a difference of $12 \%$ is observed.

\section{Summary}

Based on the results obtained from measurements and models. It can be said that there is a calculation that can determine the evaporation rate and it can produce results that are identical to experimental.

It can be seen how different air flow speeds affect the rate of evaporation, which allows more hazardous substances to be released directly into the atmosphere. A wind speed of $2 \mathrm{~m} / \mathrm{s}$, which is relatively common in an open-air environment, it will result in much faster evaporation than in an environment with negligible air flow.

The tables show which models are close to the experimental results and which models are not recommended for calculating the evaporation of a pool or other type of liquid surface. For acetone and substances with similar chemical and physical properties, Model 4 can give a good approximation of the evaporation rate.

The study provides a good basis for further research, for the investigation of additional evaporation regimes and for experimental and simulation studies of the propagation of evolved vapour clouds.

\section{References}

[1] (2021, September 15). Acetone phase diagram. Engineering ToolBox. https://www.engineeringtoolbox.com/acetone-2-propa

[2] Crowl, D. A., Louvar, J. F. (2011). Chemical process safety: Fundamentals with applications. Third edit. Boston: Pearson Education.

[3] van den Bosch, I. C. J. H., Weterings, R. A. P. M., Duijm, N. J., Bakkum, E. A. and Mercx, W. P. M. (1997). TNO, Methods for the calculatuon of physical effects "Yellow Book" CPR14E Part 1. Third edit. den Hauge, The Netherlands: National Institute of Public Healt and Envrioemnt (RIVM). 
[4] Tiemessen, ir. G. W. M., Heitink, ir. J. (1999). TNO, Guidlines for quantitaive risk assessment "Purple Book" CPR18E Part 1:Establishments. First edit. den Hauge, The Netherlands: National Institute of Public Healt and Envrioemnt (RIVM).

[5] Fábry, G. (1989). Vegyipari gépek és müveletek III. Budapest: Tankönyvkiadó.

[6] Gulyás, L. (2011). Diffúziós müveletek. Debrecen: Debreceni Egyetem, Müszaki Kar.

[7] Sattler, K. (1983). Termikus elválasztási módszerek. Budapest: Müszaki könyvkiadó.

[8] Treybal, R. E. (1961). Diffúziós vegyipari müveletek. Budapest: Müszaki könyvkiadó.

[9] Olander, L. (1994). Equations and formulas for air and air contaminants. A literature review. Solna, Sweden: Arbets Miljo Institute, National Institute of Occupational Health.

[10] Risk management program quidance for offsite consequebce analysis. United States Environmental Protection Agency, 1994.

[11] Preferred and alternative methods for estimating air emission from paint and ink manufacturing facilites. Eastern Research Group, 2000.

[12] Brilliantov, V. N., Pöschel, T. (2004). Kinetic theory of granular gases. Oxford University Press, Oxford. https://doi.org/10.1093/acprof:oso/9780198530381.001.0001 